\title{
Relationship between Branding and Customer Purchase Behaviour among Pay Television Companies in Eldoret Town-Kenya \\ Joan Chepchumba*
}

Moi University Eldoret, Kenya

DOI: $10.36347 /$ sjebm.2020.v07i12.004

| Received: 29.11.2020 | Accepted: 12.12.2020 | Published: 14.12.2020

*Corresponding author: Joan Chepchumba

Abstract

Original Research Article

Branding is often said to affect the buying behaviour of customers. The customers' decision to buy a product may be influenced positively if the brand image is positive thus customers purchase the product over and over repeating the same purchase. This study sought to determine the relationship between branding and customer purchase behaviour. The study was conducted in Eldoret Town, Kenya in a Pragmatic world view. A mixed methods research design was used employing both qualitative and quantitative techniques. The study targeted all individuals/homes who owned Pay TV decoders in the town and company stakeholders. Using Survey's [20] formula, a sample of 400 participants was therefore obtained comprising of 394 pay TV decoder customers and 6 stakeholders in the respective companies. By use of questionnaires and interview schedule, the data was collected after which analysis were done descriptively and using inferential statistics. From the findings of the study, it was established that purchasing behaviour was wholly influenced by communication of the brand values by the creator of the brand.

Keywords: branding, repeat purchases, buying behaviour, buying decision.

Copyright $\odot 2020$ The Author(s): This is an open-access article distributed under the terms of the Creative Commons Attribution 4.0 International License (CC BY-NC 4.0) which permits unrestricted use, distribution, and reproduction in any medium for non-commercial use provided the original author and source are credited.

\section{INTRODUCTION}

Before they make any decision to purchase a product or a service, consumers often put into consideration some attributes. Ashraf, Naeem and Shahzadi [1] recognize that branding is an important part of developing a product or service and hence brand image is one of these characteristics that customers look into. A brand image reflects the product that one has in mind before making a purchase. In their study they were interested in determining that relationship between brand image and consumers buying behavior and used questionnaires to collect data from 170 respondents. The study findings based on the regression model results showed a strong relationship between dependent variable and independent variables.

Consumer behavior may also be described as a set of procedure through which customers engage in while selecting, purchasing and using products / services with an aim to satisfy their needs. Customers assess the brand image, quality, prices, user convenience and performance features before they make a purchase [2]. According to Wani and Agarwal [3], consumer behavior assesses the customers as well as the products they intend to purchase so as to as to shape their identities.
Customer conduct also used to refer to consumer behavior, is the, when, why, how, and where an individual does or doesn't buy merchandise. Consumer behavior, mergers elements from mind-set, sociology, communal anthropology and finances and tries to comprehend the impact of products on client's purchasing verdict, both independently and in sets. It studies properties of distinct clients like demographics and behavioral elements in an effort to understand a person's needs. In addition, customer conduct attempts to assess effects on the customer from sets like household, friends, orientation sets, and society as a whole. According to Zeb et al. [4], when a product owns strong character that is steady with the customer's appearance, the customer will have better favorites to the product. Constructive product boldness has a direct influence on customer participation in all products. Therefore, it is assumed that product boldness has an important influence on customer participation in Pay TV products.

The Consumer Based Brand Equity (CBBE) prototypical from Strategic Brand Management by Keller [5] proposes that for a product to attain the Brand Loyalty level it has to at minimum have some salience and opinions of uniformity to be able to contest in the trade place though, it is important that a product differentiates itself from the struggle by having 
exclusive facts of distinction to be able to make above and over the various selections existing to the customer in today's contesting market. The prototypical shows and pressures the significance of being the favoured product in the outlook of the customer since labelling has frolicked the key function in a situation which is flooded with hundreds of selections from a merchandise or amenity.

Customers deliberately want to include themselves with certain products and this forms an impact in their purchasing behaviour. The impetuous clients may not care on the products as much unless prejudiced by other factors such as price or elevation however, normally an organized purchase choice can be meaningfully influenced by trading and different products. Aggressive trading focused administrations are steadily using lifestyle trading (Apple as an example) which activates the consumer purchasing conduct and the essential to belong to a means or a set connected with complexity and style.

\section{METHODOLOGY}

According to Creswell [6] the philosophical worldview is a basic set of beliefs that guide actionsalso known as paradigms, epistemologies and ontologies. It is therefore the general orientation about the world and the nature of research that may either be qualitative, quantitative or use mixed methods approaches [9]. In this paper, the author adopts a mixed approach method approach.

Any work of research makes reference to any of the four world views thus; positivism, constructivism, advocacy/participatory and pragmatism [10]. Focusing on pragmatism that was embraced by this study, Cohen and Swerdlik [10] opine that it is not committed to any one system of philosophy; instead, it focuses on the research problem and uses all the approaches available to solve it. The pragmatic world view is a combination of constructivism and interpretivism hence a mixed approach was employed, allowing the use of qualitative techniques through use of interview schedule and quantitative techniques through questionnaire [6].

Commenting on the mixed methods approach, Creswell [7] observes that:

...a mixed methods approach is one in which the researcher tends to base knowledge claims on pragmatic grounds (e.g., consequence-oriented, problem-centred, and pluralistic). It employs strategies of inquiry that involve collecting data either simultaneously or sequentially to best understand research problems ( $\mathrm{p}$. 18).

Brand owners including Pay TV Companies through their sales, influence consumer purchase decisions and hence behaviour in one way or another. The reality of a brand is constructed by the brand owner and communicated to the consumer, inform of advertisements. Following these advertisements therefore, a customer may opt to buy or not to buy the product/service. In the end the client gets the satisfaction or dissatisfaction that will lead to either brand loyalty or brand defection. On the other hand, quantitative data is numerical and standardized. As such, quantitative studies rely on numbers and figures. The qualitative data were collected using interviews, while the quantitative data was collected using questionnaires.

The study was conducted in Eldoret town, in Uasin Gishu County. The town and the county are well connected to other parts of the country thus creating the right environment for a growing market for pay TV. According to Dataxis [11] StarTimes DTT, MultiChoice's DSTV, GOtv DTT and Zuku TV are the major Pay TVs in Eldoret town. The study thus targeted all individuals/homes who owned Pay TV decoders in the town. A sample frame of 400 participants was then drawn from the target population as shown in (Table 1). A sampling frame is a list of cases or individuals from which a sample can be selected to form the units of observation in a study [8]. Simple random sampling and snowballing techniques were employed in choosing the study participants with focus on the town's administrative regions: Eldoret North, the study picked Huruma Estate, Kapsoya Estate for Eldoret East and Poineer Estate for Eldoret South. The total number of households was established as 8,497 households for Kapsoya Estate, 11,794 households for Huruma Estate and 4,252 households for Pioneer/Elgon View Estate $[12,11]$ thus giving a total of 24,723 households. Simple random sampling technique was then used to select a representative sample from each estate. Therefore, the sample size for the study was calculated using the formula advanced by Fluid Survey [13] as shown below:

Where:

$$
n=\frac{N}{1+N e^{2}}
$$

$$
\begin{aligned}
\mathrm{n} & =\text { Sample size } \\
\mathrm{N} & =\text { Population size } \\
\mathrm{e} & =\text { the error of Sampling }
\end{aligned}
$$

The study allowed for an error of sampling at 0.05 . Thus, on substitution, the sample size was as follows:

$$
\mathrm{n}=\frac{24723}{1+24723\left(0.05^{2}\right)}=394 \text { respondents }
$$


Table-1: Sample Size

\begin{tabular}{|l|l|l|l|l|}
\hline Estate & Target Population & Sample Size & Number of Households & \% of Total Households \\
\hline Kapsoya & 8497 & $\frac{8497}{24723} \times 394$ & 135 & 34.3 \\
\hline Huruma & 11974 & $\frac{11974}{24723} \times 394$ & 191 & 48.5 \\
\hline Pioneer/Elgon View & 4252 & $\frac{4252}{24723} \times 394$ & 68 & 17.2 \\
\hline Total & & & $\mathbf{3 9 4}$ & $\mathbf{1 0 0}$ \\
\hline
\end{tabular}

For the stakeholders/agents, the study employed the snowballing method where the selected case/cases then selected others that they know have required characteristics until the number of cases required was reached [14] The sample size therefore comprised 394 Pay TV consumers and 6 stakeholders/agents totalling 400 respondents.

An instrument is the means through which the researcher collects data from the sample population. As stated by Kothari [15], the most commonly used instruments are questionnaires, interview schedules, observation forms and standardized texts. According to Jwan and Ongondo [4], the techniques commonly used in qualitative research, especially in the social sciences, include: interviewing, focus group discussions, observations, analysis of documents and physical objects, and using journals among others. In this study, the quantitative data was reached at via use of questionnaires while the qualitative data was gathered by use of interview schedule.

A questionnaire guide [16] and interview schedule [10] were the main methods of data collection. Analysis of the collected data was done using the Statistical Package for Social Sciences ver. 20.0 (SPSS $\mathrm{v}$ 20.0). Pearson product moment correlation coefficient was computed to test strength of the relationship between variables. Simple linear regression analysis was computed to determine the statistical relationship between the independent variables and the dependent variable. Data from the quantitative methods was analyzed and presented in tables while he interviews were presented thematically.

\section{RESULTS AND DISCUSSION}

Understanding customer behaviour is the first step in identifying those stimuli that affect the decisionmaking process. Branding becomes effective when organizations understand how individuals make their decisions to spend their available resources like time, money and effort on consumption related items. In this regard, Pay TV providers must familiarize themselves with what their customers want to buy, why they want to buy it, when they buy it, where they buy it and how often they buy.

By analysing customer's characteristics and decision processes, marketers develop strategies to influence the choices consumers make and thus gaining a competitive advantage in the market place.

From the interview schedule the author sought to know what factors determine the clients purchasing behaviour. The following responses were received from the various participants respectively:

Agent 1: The reception of the decoder.

Stockist 2: Price of the decoder.

Stockist 4: Tariffs (Subscription rates).

Stockist 2: Programme packaging.

As the study identified the above as some of the factors that drive the purchase behavior of customer in PAY TV companies, other studies including that of Bansah, Dabi, Edem Dzorvakpor and Nwodo [13] established that branding (brand equity) accompanied with other factors of price, status, self-concept and lifestyle are key components were positively correlated with customers buying decision in the fabric industry. Design was however found to be the most influential factor.

A further analysis of the study findings indicated a statistically significant positive relationship between emotions and customer purchasing behaviour when the underlying products establish satisfaction and, as a consequence, if a product is referred, or is experienced, customers are ingrained to purchase from their satisfaction levels. The findings of this study mirror the sentiments of Hsieh, Pan, and Setiono [17] who argued that branding influenced customer purchasing behaviour. Consequently, this study avers that branding plays a positive role on organizational promotion and brand confidence in Pay TV in Eldoret Kenya since it stimulates purchasing behaviour. Table 2 presents these findings. 
Table-2: Factors that Influence Respondents"' Purchasing Behaviour

\begin{tabular}{|l|l|l|}
\hline Factor & Mean & Standard Dev. \\
\hline Pay TV Overall Image & 3.8 & .62 \\
\hline Reception of the Pay TV Signal & 3.9 & .92 \\
\hline Pay TV History/Heritage & 3.2 & .92 \\
\hline Cost of Pay TV & 4.1 & .86 \\
\hline Respondent's Age & 4.0 & .73 \\
\hline Respondent's Level of Education, & 3.9 & .73 \\
\hline Influence from Family/Friends, & 3.0 & .96 \\
\hline Pay TV Marketing Strategies & 3.4 & .94 \\
\hline
\end{tabular}

As shown in Table 2, Pay TV overall image had a mean of 38 with a standard deviation 0.62 , reception of the Pay TV signal had a mean of 3.9 with a standard deviation 0.92, Pay TV history/heritage had a mean of 3.2 with a standard deviation 0.92, cost of Pay TV had a mean of 4.1 with a standard deviation 0.86 , respondent's age had a mean of 4.0 with a standard deviation 0.73 , respondent's level of education had a mean of 3.9 with a standard deviation 0.73 , influence from family/friends had a mean of 3.0 with a standard deviation 0.96, and Pay TV marketing strategies had a mean of 3.4 with a standard deviation 0.94 . This shows that the respondents were highly influenced by cost of Pay TV and respondent's age. Other major influences include respondent's level of education and Pay TV overall image. It is therefore paramount that Pay TV providers channel their efforts towards addressing these aspects of customer purchasing behaviour.

Regarding branding strategies and customer purchasing behaviour, branding instils a level of guarantee that a product will deliver a set of promises that are communicated in the branding of the product. Through this feature, the decoders of Pay TV providers who had done adequate branding were in a position to stand out and gain a competitive advantage over a less known product whose organizations had not done adequate branding. This means that since the Pay TV providers are competing for the disposable income of consumers, they need to work on enhancing their image so as to capture the consumer's attention and influence their purchasing behaviour.

An analysis of the findings from the interviews revealed that brand equity, a resultant product of branding, was instrumental in enabling the respondents differentiate between a product and a brand. For instance, DSTV, Zuku, GoTv, Star Times and Azam are Pay TV providers who provide Pay TV services to the respondents but what sets them apart is the amount of investment a company has placed on their product. The respondents intimated that they were more likely to make a choice among these providers since their branding instils confidence in them when they are making a purchasing decision.

In essence, branding is recognized as one of the most interesting marketing strategies employed by various companies with an aim to win or overcome competition [18]. Nonetheless, studies have indicated that branding accounts for at least a third - half of all consumers at least a third - to win or the product or service $[13,19]$.

\section{CONCLUSION}

As depicted in the study findings, the decoders of Pay TV providers who had done adequate branding were in a position to stand out and gain a competitive advantage over a less known product whose organizations had not done adequate branding. This means that since the Pay TV providers are competing for the disposable income of consumers, they need to work on enhancing their brand image so as to capture the consumer's attention and influence their purchasing behaviour.

\section{RECOMMENDATIONS}

- The world is dynamic and change is inevitable. Pay TVs should be on the lookout for social and environmental changes/trends that affect customer purchasing behaviour. The programme packaging should be sensitive to the emerging trends to retain the customers. The communication channels for complains and suggestions should be at par with the emerging trends e.g. use of social media.

- The study recommends that other studies be further conducted in a different setting on a wider scale to cover a larger geographical area.

\section{REFERENCES}

1. Ashraf M, Naeem M, Shahzadi M. Impact of Branding on Consumer Buying Behavior: An Evidence of Footwear Industry of Punjab, Pakistan. International Journal of Academic Research in Business and Social Sciences. 2017;7(7):592-603.

2. Zhang Y. The impact of brand image on consumer behavior: A literature review. Open journal of business and management. 2015 Jan 8;3(01):58.

3. Wani ZA and Agarwal S. Impact of Brand on Consumer Buying Behavior. World Wide Journal of Multidisciplinary Research and Development. 2017; 3(9): 1-6

4. Zeb H, Rashid K, Javeed MB. Influence of brands on female consumer's buying behavior in Pakistan. International Journal of Trade, Economics and Finance. 2011 Jun 1;2(3):225. 
Joan Chepchumba., Sch J Econ Bus Manag, Dec, 2020; 7(12): 451-455

5. Keller KL. Brand synthesis: The multidimensionality of brand knowledge. Journal of consumer research. 2003 Mar 1;29(4):595-600.

6. Creswell JW. Research Design: Qualitative, Quantitative, and Mixed Methods Approaches. 2009. Los Angeles: Sage

7. Creswell JW. Research Design: Qualitative, Quantitative and Mixed Methods Approaches $\left(2^{\text {nd }}\right.$ Ed.) Lincoln: University of Nebraska. 2003.

8. Yoshikawa H, Weisner TS, Kalil A, Way N. Mixing qualitative and quantitative research in developmental science: Uses and methodological choices. Developmental psychology. 2008 Mar;44(2):344.

9. Scotland J. Exploring the philosophical underpinnings of research: Relating ontology and epistemology to the methodology and methods of the scientific, interpretive, and critical research paradigms. English language teaching. 2012;5(9):9-16.

10. Cohen RJ, Swerdlik ME. Test development. Psychological testing and assessment.2010.

11. Chepkole WP. Determinants of Household Solid Waste Management in Kenya: A Case of Eldoret Municipality. Unpublished MA Thesis, the University of Nairobi, Nairobi.2014.

12. KNBS K. Census Vol II Table 4: Activity Status by districts| Open Kenya| Transparent Africa.

13. Bansah PF, Dabi M, Edem Dzorvakpor SA and Nwodo H. The Effect of Branding on Consumer
Buying Behaviour among Textile Ghana Fabric Users in the Ho Municipality of Ghana. European Journal of Business and Management. 2015; 7(26), $117-125$

14. Kombo DK and Tromp DL. Proposal and Thesis Writing. Nairobi: Paulines Publications. 2006.

15. Kothari CR. Research methodology: Methods and techniques. New Age International; 2004.

16. Mugenda OM, Mugenda G.A. Research methods.2003.

17. Hsieh MH, Pan SL, Setiono R. Product-, corporate, and country-image dimensions and purchase behavior: A multicountry analysis. Journal of the Academy of marketing Science. 2004 Jul;32(3):251-70.

18. Ogbuji CN, Anyanwu AV, Onah JO. An empirical study of the impact of branding on consumer choice for regulated bottled water in southeast, Nigeria. International Journal of Business and Management. 2011 Jun;6(6):150-66.

19. Farhana M. Implication of brand identity facets on marketing communication of lifestyle magazine: case study of a Swedish brand. Journal of Applied Economics and Business Research. 2014 Mar 1;4(1):23-41.

20. Kenya National Bureau of Statistics. Statistical Release: Gross Domestic Product and Balance of Payments, Third Quarter 2015. Retrieved April 5 2016 from: http://www.knbs.or.ke/index.php? 